\title{
Prior Return Patterns in Sector Returns: Evidence for Emerging Markets
}

\author{
Sanjay Sehgal \\ Professor of Finance, University of Delhi \\ Sakshi Jain \\ Research Associate, University of Delhi
}

$\begin{array}{ll}\text { Received: March 28, } 2012 & \text { Accepted: May 5, } 2012 \quad \text { Published: June 1, } 2012 \\ \text { doi:10.5296/ajfa.v4i1.1560 } & \text { URL: http://dx.doi.org/10.5296/ajfa.v4i1.1560 }\end{array}$

\begin{abstract}
In this paper, we examine if there are any prior return patterns for sector returns for BRICKS markets from January 1993 to February 2008. For short-term portfolio formation windows (up to 12 months), India and S.Africa report momentum behavior while South Korea reports reversals. For long-term formation windows (up to 60 months), Brazil exhibits momentum patterns which disappear for 60-12-12 strategies. India and Russia momentum patterns continue even for long-term portfolio formation windows South Korea, South Africa and China show weak reversals for long-term portfolio formation windows. We construct a sector factor based on Liu and Zhang (2008) argument that winner sector exhibit higher risk owing to stronger growth potential. We observe that a large part of prior return patterns in stock returns are absorbed by similar patterns in sector returns. Our findings shall be useful for portfolio managers and academicians with better insights about prior return patterns in sector data. The study contributes to the asset pricing and behavioral finance literature for emerging markets.
\end{abstract}

Keywords: CAPM, Momentum, Contrarian, Fama French model, Sector returns, Behavioral finance

JEL CODE: C51, C52, G12, G14, G15 


\section{Introduction}

Goldman Sachs in 2001 coined the term BRICs for the fast developing economies of Brazil, Russia, India and China and they collectively may rival the G7 economies in terms of global growth by 2050. The economists at Goldman Sachs believe that the BRIC countries will grow at a significantly higher rate than the developed economies. The BRICs acronym has been extended to BRICKS in this paper, which includes the emerging economies of South Korea (K) and South Africa (S). Korea is an industrial leader in electronics, ship-building and global trading and South Africa is the economic force of the African continent and hence are important emerging markets. These financial markets have attractive investment opportunities with a striking risk/return ratio. Over the last decade, these economies have contributed one third in terms of GDP growth.

BRICKS represent one of the most active segments of emerging markets. They are on the radar of global portfolio managers owing to the belief that emerging markets exhibits low degree of co-relation with mature markets. During recent years, with liberalization and deregulation in these emerging markets, global investors have many opportunities to invest. These investors are continuously on the look out for trading strategies that can exploit observable market inefficiencies and generate extra normal returns.

Researchers have found that simple trading strategies based on past cross-section of stock returns can generate extra normal profits. Practitioners and investors try to exploit the persisting anomalies (Value effect, size effect, the January effect, lead-lag effects, mean reversal of long-term losers, and momentum of short-term winners) of stock market to earn profits. Among them, long-term reversals (contrarian) and short-term continuation (momentum) have received particular attention over the last three decades. The contrarian strategies perform well for very short term (up to 3 months), see Lo and MacKinlay (1990) and long term (3 years - 5 years), see De Bondt and Thaler, $(1985,1987)$ while momentum strategies perform well for short term (between 3months - 12 months), see Jegadeesh and Titman, (1993).

In the last three decades, these prior return patterns in stock returns have been extensively evaluated for mature ${ }^{1}$ as well as emerging markets ${ }^{2}$. Since the end of nineties, a body of literature has emerged that concentrates on prior return patterns in sector returns and which advocates that these sector patterns tend to drive prior return patterns in stock returns. The belief here is that the stocks within a sector have a lot in common in terms of business perspectives and hence winner stocks may owe there success to being a part of winner sectors while loser stocks may belong to poor performing sectors. There is also some empirical evidence which suggests that the role of sector factor in stock returns is over emphasized.

Moskowitz and Grinblatt (1999) were the first to document strong momentum effect in Industry components of stock returns. Asness, Porter and Stevens (2000) find that within-industry momentum has predictive power for the firm's stock returns beyond that captured by across industry momentum and also there is a significant short-term (one-month) industry momentum effect. Neal (2000) provides evidence of industry momentum over intermediate time horizons by the performance of industries in mutual funds. Serra (2000) 
document that cross-market diversification seems better than cross-industry diversification, for emerging markets, returns are driven by country factors and not by the industrial composition of indices. Nijman, Swinkels and Verbeek (2004) suggest that positive expected excess returns are primarily driven by individual stock effects, while industry momentum plays a less important role and country momentum is even weaker. Du and Denning (2005) find that industry momentum is mainly due to common factors and not industry-specific risk. Scowcroft and Sefton (2005) indicate that price momentum is driven by industry momentum.

Menzly and Ozbas (2006) find strong cross-industry momentum for industries related to each other through supply chain. Bonie and Kent (2006) report that short-term industry price momentum phenomenon is partly explained by returns of firms with more analyst coverage leading those with less analyst coverage. Phylaktis and Xia (2006) show that global and industry effects are dominated by country effects in emerging markets, which is contrary to the evidence on mature markets. Chen, Benett and Zheng (2006) suggest investors should emphasize sector based approach in developed countries but continue country-based allocation strategies for emerging markets. Saffieddine and Sonti (2007) report firms with highest industry growth quintile have significantly higher momentum compared to industries in lowest growth quintile. Liu and Zhang (2008) document that growth rate of industrial production is a risk factor in asset pricing tests and can explain more than half of stock momentum profits. Fraulo and Nguyen (2009) replicate Moskowitz and Grinblatt's work and find that industry momentum strategies do provide greater returns than individual stock momentum strategies and also the optimal time horizon of industry momentum strategy has no correlation with the size of the industries. They also find that the $(6,6)$ and $(12,12)$ strategies are unaffected by the one-month return, confirming our previous intuition that these strategies are uncontaminated by any potential short-term effects due to microstructure or liquidity.

While focusing in industry patterns in stock returns, it is important to understand that industry classification systems which are currently in vogue. There are several ${ }^{3}$ industry classification systems which are being used worldwide. Amongst these Global Industry Classification System (GICS) provided by Standard \& Poor's (USA) in collaboration with Morgan Stanley Capital International (MSCI) is extremely popular and hence extensively employed by market players as well as empiricists. GICS is a four digit classification system involving 10 sectors, 24 Industry groups, 68 industries and 154 Sub-Industries. One may discern different prior return patterns for each stage of industry classification that is sector, industry group, industry and sub-industry.

There is limited literature for emerging markets that covers sector based prior return patterns. In this paper we examine the following propositions for BRICKS which is a fast growing emerging market basket closely tracked by global investment managers. (1) Are there any prior return patterns at sector, Industry and Industry group level? (2) Do these prior return patterns differ for short-term (up to 12 months) and long-term (24-60) portfolio formation windows? (3) Do winner and loser sector exhibit different growth potential, the information about which then can be used to construct a sector factor as suggested by Liu and Zhang 
(2008)? (4) Can the sector factor capture prior return patterns in stock returns that are missed by CAPM and the Fama French three-factor model?

The main focus of the study is to test prior return patterns for sector returns especially for emerging markets. We find in case of sector returns, for short-term portfolio formation windows (up to 12 months), India and S.Africa reports momentum behavior while S. Korea reports reversals. For long-term formation windows, Brazil exhibits momentum patterns which disappear for 60-12-12 strategies. For India and Russia momentum patterns continue even for long-term portfolio formation windows. S.Korea, S.Africa and China show weak reversals for long-term portfolio formation windows. The differences in growth rate of sectors of winners and losers may be able to explain risk as documented by Liu and Zhang (2008). It is expected that the sector factor, which mimics the growth risk differences between corner portfolios, should be able to provide a better explanation based on short-term prior return formation. In case of long-term portfolio formation, the sector factor is likely to absorb cross-section of average returns in case of Brazil, Russia and India'. We construct a sector factor based on Liu and Zhang (2008) argument that winner sector exhibit higher risk owing to stronger growth potential. Our results are stronger for short-term portfolio formation windows for all the sample countries and for long-term portfolio formation windows in case of Brazil, Russia and India.

The remainder of the paper is structured as follows: Section 2 gives a brief description of data and their sources. In section 3, we test for any prior return effects in sector, Industry and Industry group. Section 4 describes the methodology employed and examine the evidence for four-factor model with constructed sector factor as the additional factor to Fama-French three factor model and the empirical tests carried out related to sector momentum portfolios. Section 5 concludes.

\section{Data and Their Sources}

Data comprises of monthly share prices adjusted for stock splits, stock dividends and rights issues for BRICKS markets and has been obtained from Thomson Reuters DataStream software. The sample period is from January 1993 to February 2008 except for Russia where the sample period is January 2000 to February 2008 due to paucity of data. Exhibit A gives the number of securities that have been used for analysis along with market indices and their description for the sample countries. The companies account for a reasonable part of market capitalization and trading activity in their respective markets. Hence, our data set fairly represents market performance. 
Exhibit A: Data Description for Sample Countries

\begin{tabular}{|c|c|c|c|}
\hline Country & $\begin{array}{ll}\text { No. } & \text { of } \\
\text { Securities }\end{array}$ & Market Index & Index Description \\
\hline Brazil & 195 & $\begin{array}{l}\text { BRAZIL } \\
\text { BOVESPA }\end{array}$ & $\begin{array}{l}\text { BM\&FBOVESPA S.A. ia a security market index with base } \\
\text { year } 1968 \text { and base value of } 100 \text {. It is a total return index and } \\
\text { handles about } 85 \% \text { of the total volume traded on country's nine } \\
\text { stock exchanges. }\end{array}$ \\
\hline Russia & 75 & $\begin{array}{l}\text { RUSSIA RTS } \\
\text { INDEX }\end{array}$ & $\begin{array}{l}\text { The Russian Trading System Index is a capitalization-weighted } \\
\text { index. The index was developed with a base value of } 100 \text { in } \\
\text { 1995. It uses free float adjusted weights. }\end{array}$ \\
\hline India & 450 & $\begin{array}{l}\text { INDIA } \\
\text { BSE-200 } \\
\text { (SENSEX) }\end{array}$ & $\begin{array}{l}\text { BSE-200 index is a free-float value weighted index that } \\
\text { represents nearly } 93 \% \text { of the total market capitalization on the } \\
\text { Bombay Stock Exchange. The financial year } 1989-90 \text { has been } \\
\text { chosen as the base year. }\end{array}$ \\
\hline China & 600 & $\begin{array}{l}\text { SHANGHAI } \\
\text { SE A SHARE }\end{array}$ & $\begin{array}{l}\text { The Shanghai A-Share Stock Price Index is a market } \\
\text { capitalization-weighted index. The index was developed with a } \\
\text { base value of } 100 \text { on December 19, 1990. It comprises of all the } \\
\text { A-shares which are restricted to trading by local investors and } \\
\text { qualified institutional foreign investors. }\end{array}$ \\
\hline Korea & 500 & $\begin{array}{l}\text { KOREA SE } \\
\text { COMPOSITE } \\
\text { (KOSPI) }\end{array}$ & $\begin{array}{l}\text { The KOSPI } 200 \text { index consists of } 200 \text { Korean stocks which } \\
\text { constitute } 93 \% \text { of the total market value on the Korea Stock } \\
\text { Exchange. The index was developed with base value of } 100 \text { in } \\
\text { the year } 1990 \text {. }\end{array}$ \\
\hline $\begin{array}{l}\text { South } \\
\text { Africa }\end{array}$ & 250 & $\begin{array}{l}\text { FTSE/JSE } \\
\text { Africa ALL } \\
\text { SHARE }\end{array}$ & $\begin{array}{l}\text { The FTSE/JSE All Africa Index Series is designed to represent } \\
\text { the performance of the top African companies listed on } \\
\text { Johannesburg Stock Exchange. Companies included consist of } \\
\text { top } 99 \% \text { of the total pre-free float market capitalization. The } \\
\text { FTSE/JSE Africa Index Series replaced the JSE Actuaries } \\
\text { indices on the } 24 \text { th of June } 2002 \text {. }\end{array}$ \\
\hline
\end{tabular}

Monthly share prices for estimation purposes and further analysis have been converted to percentage monthly return series. The stylized portfolios are formed on basis of past percentage returns ${ }^{4}$ and characteristics and Past Sales Growth ${ }^{5}$ (estimated as compounded 
value of Net Sales). 91-day ${ }^{6}$ treasury bills for each country have been used as risk free proxy. Value-weighted market index has been used as surrogate for aggregate economic wealth. Data for above said firm characteristics and market index has also been obtained from Thomson Reuters DataStream.

Global Industry Classification System (GICS) is an industry classification system, developed by Standard \& Poor's (USA) in collaboration with Morgan Stanley Capital International (MSCI). It comprises of 10 sectors, 24 Industry groups, 68 industries and 154 Sub-Industries. GICS was developed in response to the financial community's need for one complete, consistent set of global sector and industry definitions. The GICS standard can be applied to companies globally, in both developed and developing markets. In our work information for sectors, industry group and industry have been used. The 10 prominent sectors are Energy, Materials, Industrials, Consumer Discretionary, Consumer Staples, Health Care, Financials, Information Technology, Telecommunication Services and Utilities. The data for sector, industry group and industry classification has been obtained from World Scope, Reuters Financials \& Compustat Global.

\section{Prior Return Patterns in Sector Returns}

In this section, we evaluate if there are any prior return patterns in sector, industry group and industry data and also show how these patterns differ for short-term and long-term portfolio formation windows. The portfolios have been formed on basis of (i months-j months strategy) where i months represent portfolio formation window and $\mathrm{j}$ months represent portfolio holding period. Two types of strategies have been employed (i) short-term strategies, 6 months-6 months (6-6) and 12 months-12 months (12-12), (ii) long-term with skipping one year between portfolio formation and holding periods, 24 months-12 months -12 months (24-12-12), 36 months-12 months -12 months (36-12-12), 48 months- 12 months -12 months (48-12-12), and 60 months-12 months -12 months (60-12-12). The 12 months have been skipped to control for any short-term prior return effects as that may hamper any clear judgment of returns, as suggested by Fama and French (1996). Calendar year (January to December) has been followed from for purpose of evaluation.

\section{$\underline{\text { Short-term portfolio formation }}$}

We verify if there are any momentum patterns in sector return for BRICKS countries. For 6-6 investment strategies, in December of year t-1, we categorize the sample securities into 10 sectors according to Global Industry Classification System(GICS). GICS was developed by Standard \& Poor's (USA) in collaboration with Morgan Stanley Capital International (MSCI). It comprises of 10 sectors, 24 Industry groups, 68 industries and 154 Sub-Industries. The excess monthly return for each sector is then calculated from July to December by taking the simple average of returns on securities that form part of each of these sectors. The individual sectors are then ranked on basis of past six month's average monthly past excess returns. The ranked sectors are then classified into quintiles, K1 to K5. K1 comprises of sectors with lowest average past returns and K5 comprises of sectors with highest average past returns. Equally weighted excess returns are estimated for sector portfolios for the next six months (i.e. January to June of year t). The portfolios are then rebalanced in the month of 


\section{Macrothink}

June for year t based on ranking of six month's average monthly past sectoral returns i.e. January to June of year t. The process is repeated till we reach the end of our sample period. For 12-12 strategies, estimation has been done in similar manner except that portfolio formation and holding windows are reset to 12 months. The portfolios for industry group and industry have also been constructed in the same manner, where the ranked industry group is classified into quintiles as IG1 to IG5, IG1 and IG5 comprise of industry group with lowest and highest average past returns. In case of industry classification, the industries are labeled from I1 to I5, where I1 and I5 comprise of bottom and top 20\% of industries.

Short-term prior return patterns for sector, Industry group and industry are reported in Table 1, Panel A. We specifically evaluate zero investment long-short portfolio strategies involving buying past winners (losers) and selling past loser (winners) when there is momentum (reversal). For 6-6 strategies, South Korea and Brazil provide strong momentum profits at all levels (sector, Industry group and Industry). South Korea reports the highest monthly returns of 3.2\% at sector level, while Brazil provides the highest return of 3.8\% and 4.1\% on monthly basis at industry group and industry level. India, S.Africa and Russia also report momentum profits at all levels. For China, the prior return patterns at all the three levels are negligible. For Brazil, South Africa and China, the returns increase as we move from sector to industry level, however India does not report any clear patterns. For 12-12 strategies, the prior returns become weaker compared to 6-6 strategies. For Brazil and China, the returns are negligible and in fact die out in case of former. India reports momentum only at sector level, while South Africa reports strong momentum at industry group and industry level. For Korean market, there are strong reversals at all the three levels. In sum: For 6-6 strategies, we report momentum for all the sample countries with exception of China. For 12-12 strategies, in case of India and South Africa the momentum pattern persists, South Korea reports strong reversals, and the prior return patterns die out for other BRICKS markets.

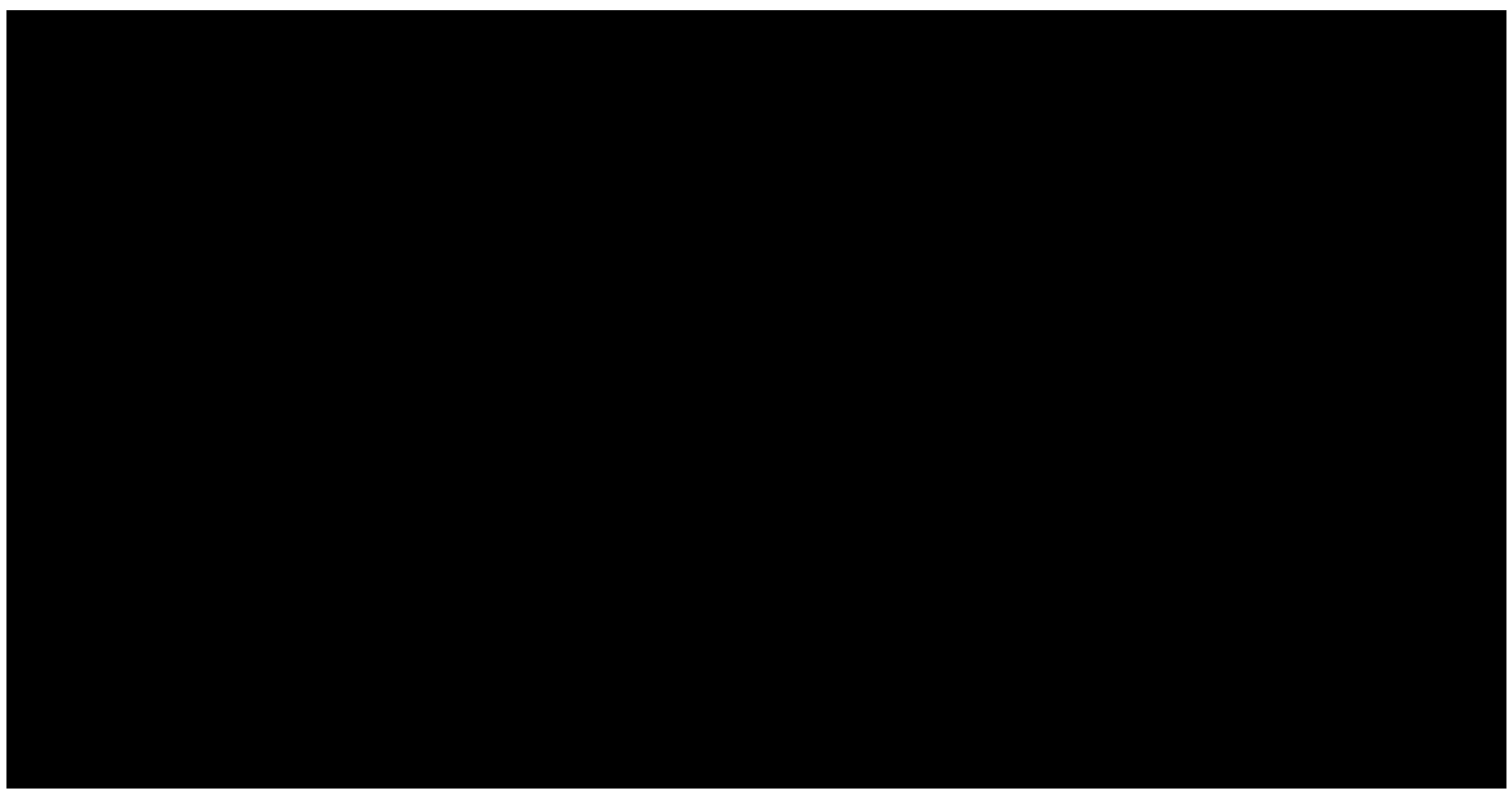

Long-term portfolio formation 
In case of long-term strategies, (24-12-12, 36-12-12, 48-12-12, and 60-12-12), for 24 months-12 months-12 months strategy, in December of year t-2, sample securities have been categorized into 10 sectors according to GICS. The excess monthly return for each sector is then calculated from January to December by taking the simple average of returns on securities that form part of each of these sectors. The individual sectors are then ranked on basis of past twenty four month's average monthly past excess returns. The ranked sectors are then classified into quintiles, $\mathrm{K} 1$ to $\mathrm{K} 5$. K1 comprises of sectors with lowest average past returns and $\mathrm{K} 5$ comprises of sectors with highest average past returns. Equally weighted excess returns are estimated for sample portfolios skipping 12 months between portfolio formation and holding windows (i.e. January to December of year t-1) and the portfolios are rebalanced every 12 months based on double sorting criteria for the year t. For 36-12-12, 48-12-12 and 60-12-12 strategies, estimation has been done in similar manner. The portfolios for industry group and industry have also been constructed in the same manner.

The results are reported in Table 1, Panel B. For 24-12-12 strategies, Russia (2.3\% on monthly basis) and India (3.0\% on monthly basis) reports strong momentum at sector level. Brazil reports weak momentum at all levels while China, South Korea and South Africa report weak reversals. For 36-12-12 strategies, same patterns are observed as 24-12-12 strategies. For Russia and India the momentum patterns have become strong at sector level. Brazil reports momentum behavior in all the three cases and the returns are stronger than 24-12-12. For 48-12-12 and 60-12-12 strategies, the countries report similar patterns. In sum: Brazil and Russia report momentum up to 48-12-12 and for 60-12-12; while the former reports weak contrarian patterns at sector level, while latter reports small momentum returns at sector, level. India reports strong momentum at sector level up to 60-12-12 strategies, however for Industry and Industry group, weak reversals patterns emerge. China reports predominantly weak reversals pattern for all long-term portfolio formation windows. Further, in case of China, returns at sector level are always better than Industry and Industry group level. For South Korea, we observe weak reversals for all strategies except 60-12-12 strategies, where the momentum patterns emerge at sector level. In case of S. Africa, all the long-term strategies report weak reversals.

In sum, at the sector level, Russia and India report long-run momentum patterns which are stronger than that for short-term portfolio formation strategies. Brazil also exhibits momentum patterns but that are weaker for long-term compared to short-term and which disappear at 60-12-12. S.Korea, S.Africa and China show weak reversals for long-term portfolio formation windows. 


\section{Economic Rationale for the Prior Return Sector Factor}

The explanation of returns by sector factor could be linked to the differences in growth rate of sectors of winners and losers. The sector growth rates may be able to explain risk; this is motivated by the work of Liu and Zhang (2008). They find that recent winners have temporarily higher loadings for growth rate of industrial production than recent losers, and the combined effect of growth rate of industrial production loadings and risk premiums account for more than half of momentum profits. They also suggest that expected-growth risk is priced and that the expected-growth risk increases with expected growth. However, presence of other factors which may have caused differences in winner and loser cannot be ruled out.

In this paper, the sector growth rate has been estimated as follows: For 6-6 strategy, in December of year $\mathrm{t}-1$, we categorize the 10 sectors on basis of past sales growth (PSG) according to Global Industry classification System (GICS). The past sales growth is estimated as three year compounded growth rate in sales using the formula $S_{t+3}=S_{t}(1+r)^{3}$, where $S_{t+3}$ and $\mathrm{S}_{\mathrm{t}}$ are sales revenue in year $\mathrm{t}+3$ and $\mathrm{t}$ respectively. These 10 sectors are then classified in to quintiles Q1 to Q5, where Q1 comprises of bottom 20\% sectors (loser sectors) and Q5 comprises top 20\% of sectors (winner sectors). Mean value of PSG is calculated for Q1 and 
Q5 using the sector following in these quintiles on period to period basis. The sector growth is then computed by taking the average over time. The estimation for 12-12 sector growth rate has been done in similar manner. The 24-12-12 prior return strategy construction that sorts sectors based on their past 24 month's past sales growth, skips 12 month for controlling the short-term momentum effect, and hold the resulting portfolios for the subsequent 12 months. The estimation for 36-12-12, 48-12-12 and 60-12-12 strategies have been done in similar manner and we leave a gap of 12 months between portfolio formation and portfolio holding windows to control for any short-term momentum effects.

These results are reported in Table 2 for all the BRICKS markets at sector level. For both 6-6 and 12-12 strategies, we observe for all the countries that winner sectors (Q5) exhibit higher growth rates as they comprise of high growth companies compared to loser sector and hence they may be exposed to higher growth risk. Our results are consistent with Liu and Zhang (2008) argument and suggest that the sector factor proxies for a risk factor in returns. For long term portfolio formation windows, In case of India and Russia portfolio performance is consistent with growth risk story i.e. the winning sectors exhibit higher growth risk vis-a-vis losing sectors. However there are contradictions for other sample countries for one or more portfolio formation periods. Hence, 'we expect the sector factor, which mimics the growth risk differences between corner portfolios to perform better for portfolios based on short-term prior return formation. In case of long-term portfolio formation, the sector factor is likely to absorb cross-section of average returns in case of Brazil, Russia and India’.

\begin{tabular}{|c|c|c|c|c|c|c|}
\hline \multicolumn{7}{|c|}{ Table 2: Sector Growth rates } \\
\hline STRATEGY & BRAZIL & RUSSIA & INDIA & CHINA & S.KOREA & S.AFRICA \\
\hline \multicolumn{7}{|c|}{6 Months - 6 Months } \\
\hline Q1 & -0.612 & -0.035 & 0.053 & 0.033 & 0.031 & 0.036 \\
\hline Q5 & -0.228 & 0.438 & 0.463 & 0.348 & 0.239 & 0.364 \\
\hline \multicolumn{7}{|c|}{12 Months - 12 Months } \\
\hline Q1 & -0.612 & -0.015 & 0.049 & 0.033 & 0.026 & 0.026 \\
\hline Q5 & -0.263 & 0.413 & 0.298 & 0.348 & 0.235 & 0.334 \\
\hline \multicolumn{7}{|c|}{24 Months-12 months-12 Months } \\
\hline Q1 & -0.342 & 0.312 & 0.102 & 0.212 & 0.123 & 0.241 \\
\hline Q5 & -0.496 & 0.326 & 0.233 & 0.264 & 0.130 & 0.247 \\
\hline \multicolumn{7}{|c|}{36 Months-12 months-12 Months } \\
\hline Q1 & -0.326 & 0.205 & 0.112 & 0.175 & 0.127 & 0.242 \\
\hline Q5 & -0.516 & 0.253 & 0.143 & 0.198 & 0.159 & 0.232 \\
\hline \multicolumn{7}{|c|}{48 Months- 12 months-12 Months } \\
\hline Q1 & -0.347 & 0.151 & 0.108 & 0.192 & 0.121 & 0.209 \\
\hline Q5 & -0.148 & 0.230 & 0.195 & 0.230 & 0.157 & 0.274 \\
\hline \multicolumn{7}{|c|}{60 Months-12 months-12 Months } \\
\hline Q1 & -0.373 & 0.291 & 0.142 & 0.210 & 0.124 & 0.271 \\
\hline Q5 & -0.505 & 0.182 & 0.136 & 0.147 & 0.133 & 0.267 \\
\hline
\end{tabular}

\section{Role of Sector Factor in Stock Returns}

In this section, we test whether prior return patterns in stock returns are absorbed by similar patterns in sector data. We sort securities on basis of average past excess returns, for 6-6 strategies, in December of year $t-1$, the individual securities are ranked on basis of past six 
month's average monthly past excess returns. The ranked securities are then classified into quintiles, P1 to P5. P1 comprises of bottom 20\% stocks on basis of average past period returns and P5 comprises of top 20\% stocks on basis of average past period returns. We estimate the return on zero investment portfolio based on these prior return patterns in stock returns which involves buying winners (losers) and selling losers (winners) as in case of momentum (contrarian) as in case of sector data. We regress the return on zero-investment prior return stock portfolio on the sector factor (zero-investment prior return sector portfolio). The results of which are reported in table 3. Estimations for 12-12 and long-term strategies have been done in similar manner.

It can be clearly seen that returns on prior return stock portfolio load on the returns for sector factor. As expected our results are stronger for short-term portfolio formation windows for all the sample countries and for long-term portfolio formation windows in case of Brazil, Russia and India. Thus, most of the prior return patterns in stock returns are absorbed by similar patterns in sector returns. Further, the sector factor seems to be proxying for growth risk differences between winner and loser sectors and hence should be treated as an additional risk factor in a multi factor asset pricing framework.

\begin{tabular}{|c|c|c|c|c|c|c|c|c|}
\hline & \multicolumn{4}{|c|}{ Brazil } & \multicolumn{4}{|c|}{ China } \\
\hline & $\alpha$ & $\bar{\beta}$ & $\mathrm{t}(\alpha)$ & $t(\beta)$ & $\alpha$ & $\bar{\beta}$ & $\mathrm{t}(\alpha)$ & $t(\beta)$ \\
\hline 6 Months -6 Months & -0.001 & 0.085 & -0.075 & 0.635 & -0.003 & -0.992 & -0.258 & -3.596 \\
\hline 12 Months - 12 Months & 0.006 & 0.068 & 0.772 & 1.022 & 0.000 & 0.451 & -0.080 & 3.986 \\
\hline 24 Months-12-12 Months & 0.021 & 0.260 & 1.627 & 2.715 & -0.006 & 0.777 & -1.310 & 4.842 \\
\hline 36 Months-12-12 Months & 0.010 & 0.222 & 0.606 & 1.366 & -0.010 & 0.300 & -2.249 & 1.700 \\
\hline 48 Months-12-12 Months & 0.017 & -0.507 & 1.466 & -4.184 & -0.008 & 0.559 & -1.509 & 2.728 \\
\hline \multirow[t]{2}{*}{60 Months-12-12 Months } & 0.017 & -0.806 & 1.133 & -4.746 & -0.013 & 0.250 & -2.460 & 1.140 \\
\hline & \multicolumn{4}{|c|}{ Russia } & \multicolumn{4}{|c|}{ S.Korea } \\
\hline 6 Months - 6 Months & -0.001 & 0.436 & -0.034 & 4.666 & -0.019 & 0.631 & -1.074 & 4.310 \\
\hline 12 Months - 12 Months & 0.000 & 1.009 & 0.373 & 2.387 & -0.006 & 0.487 & -1.119 & 2.441 \\
\hline 24 Months-12-12 Months & 0.029 & 0.396 & 1.652 & 3.332 & -0.014 & 0.519 & -2.484 & 9.206 \\
\hline 36 Months-12-12 Months & -0.008 & 0.750 & -0.595 & 9.201 & -0.010 & 0.349 & -1.857 & 7.265 \\
\hline 48 Months-12-12 Months & 0.025 & 1.141 & 1.064 & 7.468 & -0.017 & 0.484 & -2.818 & 7.520 \\
\hline \multirow[t]{2}{*}{60 Months-12-12 Months } & 0.032 & 1.075 & 1.021 & 5.013 & -0.009 & 0.248 & -2.161 & 6.284 \\
\hline & \multicolumn{4}{|c|}{ India } & \multicolumn{4}{|c|}{ S.Africa } \\
\hline 6 Months - 6 Months & -0.014 & 0.421 & -1.146 & 3.220 & -0.003 & 0.284 & -0.346 & 2.394 \\
\hline 12 Months - 12 Months & 0.007 & 0.180 & 1.229 & 3.260 & 0.009 & 0.239 & 1.814 & 3.669 \\
\hline 24 Months-12-12 Months & -0.002 & 0.275 & -0.375 & 5.480 & 0.004 & 0.026 & 0.589 & 0.249 \\
\hline 36 Months-12-12 Months & -0.005 & 0.141 & -1.060 & 2.812 & -0.006 & 0.202 & -0.847 & 2.389 \\
\hline 48 Months-12-12 Months & 0.001 & 0.253 & 0.254 & 5.684 & -0.006 & 0.011 & -0.984 & 0.105 \\
\hline 60 Months-12-12 Months & -0.005 & 0.207 & -0.845 & 3.354 & -0.010 & 0.091 & -1.722 & 1.094 \\
\hline
\end{tabular}

\section{Summary and Conclusion}

Several academicians have documented the importance of allocation decision within a stock portfolio. The body of literature focuses mainly on prior return patterns in stock returns, however there is limited focus on prior return patterns for sector returns especially for emerging markets. In this paper we examine the following propositions for BRICKS markets (1) Are there any prior return patterns at sector, Industry and Industry group level for short-term (6-6 and 12-12) and long-term (24-12-12, 36-12-12, 48-12-12 and 60-12-12) strategies? (2) Do these prior return patterns differ for short-term (up to 12 months) and long-term (24-60) portfolio formation windows? (3) Do winner and loser sector exhibit different growth potential, the information about which then can be used to construct a sector factor as suggested by Liu and Zhang (2008)? (4) Can the sector factor capture some of the 
prior return patterns in stock returns thereby implying that winning stocks may belong to winning sectors while losing stocks may belong to losing sectors? The data period is from January 1993 to February 2008.

We find that for 6-6 strategies, the sector returns for sample countries exhibit momentum patterns with exception of China. For 12-12 strategies, in case of India and South Africa momentum pattern persists. South Korea reports strong reversals however prior return patterns die out for other BRICKS markets. For long-term portfolio formation windows, at the sector level, Russia and India report long-run momentum patterns which are stronger than that for short-term portfolio formation strategies. Brazil also exhibits momentum patterns but are weaker for long-term compared to short-term and disappear for 60-12-12 strategies. S.Korea, S.Africa and China show weak reversals for long-term portfolio formation windows.

The differences in growth rate of sectors of winners and losers may be able to explain risk as documented by Liu and Zhang (2008). For both 6-6 and 12-12 strategies, we observe for all the countries that winner sectors (Q5) exhibit higher growth rates as they comprise of high growth companies compared to loser sector and hence they may be exposed to higher growth risk. For long term portfolio formation windows, in case of India and Russia, portfolio performance is consistent with growth risk story; however there are contradictions for other sample countries. It is expected that the sector factor, which mimics the growth risk differences between corner portfolios, should be able to provide a better explanation based on short-term prior return formation. In case of long-term portfolio formation, the sector factor is likely to absorb cross-section of average returns in case of Brazil, Russia and India'.

Next, we test whether prior return patterns in stock returns are absorbed by similar patterns in sector data. We find that the returns on prior return stock portfolio load on the returns for sector factor. As expected our results are stronger for short-term portfolio formation windows for all the sample countries and for long-term portfolio formation windows in case of Brazil, Russia and India.

Our findings are relevant for investment analysts and portfolio managers who are continuously tracking global markets, in pursuit of abnormal returns. The findings also provide the academicians with better insights about prior return patterns in sector data and their impact on prior return stock patterns. The present research contributes to both asset pricing as well as behavioral finance literature for emerging markets. It is suggested that the work may be extended to other emerging markets as there is very limited literature on the subject.

\section{Notes}

1. DeBondt and Thaler (1985, 1987), Jegadeesh and Titman (1993), Rouwenhorst (1998), Chan, Jegadeesh and Lakonishok (1999), Jegadeesh and Titman (2002), Lewellen (2002), Lo and MacKinlay (1990), Ball, Kothari and Shanken (1995), Banz (1981), Chan, Lakonishok and Hamao, Basu (1977, 1983), Bhandari and Weiss (1996), Rosenberg, Reid and Lanstien (1985), Lakonishik, Shliefer and Vishny (1994), (Litzenberg and Ramaswamy(1979), Fama and French (1996), Conrad and Kaul (1998), Berk, Green and Naik (1999), Chordia and 
Shivkumar (2000), Lee and Swaminathan (2000), Jegadeesh and Titman (2002), Daniel, Hirshliefer, and Subrahmanyam (1998), Barberis, Shliefer and Vishny (1999), Hong and Stein (2000) and Goetzmann and Massa (2002), Ahn, Conrad and Dittmar (2003), Scott, Stump and Xu (2003), Kent, Hirshleifer and Subrahmanayam (2004), Shen, Szakmary, and Sharma (2005), Miffre and Rallis (2007), Antoniou, Lam and Paudyal (2007), Chen, Chen, Hsin, and Lee (2010).

2. There is a lot of evidence for the mature markets; however little evidence exists about the factors which drive the cross-section of returns in emerging markets. Rouwenhorst (1999), Froot et al. (2001), Chui et al. (2000), Kim and Wei (2002), Hameed and Kusnadi (2002), Lin and Swanson (2004) and, Swanson and Lin (2005).

3. International Standard Industrial Classification of All Economic Activities, Global Industry Classification Standard (GICS), Standard Industrial Classification (SIC), Thomson Reuters Business Classification (TRBC), North American Industry Classification System (NAICS), U.S. Securities and Exchange Commission (SEC) are the several industry classification systems.

4. Percentage Returns estimation is based on capital gains component. There is no dividend component as in India, dividend yields of companies are very low, Gupta (2000). Also, all the Bombay Stock Exchange (BSE)-500 index series do not include any dividends while computing index values. Hence, dividend inclusion in individual stock returns may bias the estimators of our proposed time series regressions.

5. Past Sales Growth is estimated as three year compounded growth rate in sales using the formula $S_{t+3}=S_{t}(1+r)^{3}$, where $S_{t+3}$ and $S_{t}$ are sales revenue in year $t+3$ and $t$ respectively. $r$ is compounded growth rate in sales termed as Past Sales Growth.

6. Annualized implicit yields on 91-day t-bills available for all weekly auctions over the study period have been used. We select the implicit yield for the last week of each month to match with month end closing prices of sample stocks. The end of month annualized implicit yields is divided by 12 to generate approximate monthly risk free yields.

\section{References}

Ahn, D.H., Conrad, J., \& Dittmar, R.F. (2003). Risk Adjustment and Trading Strategies. The Review of Financial Studies, 16 (2), 459-485. http://dx.doi.org/10.1093/rfs/hhg001

Antoniou,A., Lam,H.Y.T., \& Paudyal,K. (2007). Profitabilty of Momentum Strategies in International Markets: The roel of business cycle and behavioral biases. Journal of Banking and Finance, 955-972. http://dx.doi.org/10.1016/j.jbankfin.2006.08.001

Asness, C.S., Porter, R. B., \& Stevens, R.L. (2000). Predicting Stock Returns Using Industry-Relative Firm Characteristics. AQR Capital Management working paper . 
Ball, R., \& Kothari, S. (1989). Nonstationary Expected Returns: Implications for Tests of Market Efficiency and Serial Correlation in Returns. Journal of Financial Economics, 25, 51-74. http://dx.doi.org/10.1016/0304-405X(89)90096-2

Ball, R., Kothari, S., \& Shanken, J. (1995). Problems in Measuring Portfolio Performance : An Application to Contrarian Investment Strategies. Journal of Financial Economics, 38, 79-107. http://dx.doi.org/10.1016/0304-405X(94)00806-C

Banz, Rolf W. (1981). The Relationship between Return and Market Value of Common Stocks. Journal of Financial Economics, $\quad 9, \quad 3-18$. http://dx.doi.org/10.1016/0304-405X(81)90018-0

Barferis, N., Shliefer, A., \& Vishny, R. (1998). A Model of Investor Sentiment. Journal of Financial Economics, 49, 307-343.

Barry, C.B., Goldreyer, E., Lockwood, L., \& Rodriguez, M. (2002). Robustness of Size and Value effects in emerging Markets, 1985-2000. Emerging Markets Review, 3, 1-30. http://dx.doi.org/10.1016/S1566-0141(01)00028-0

Basu, S. (1983). The Relationship between Earning Yield, Market Value and Return for NYSE Common Stocks: Further Evidence. Journal of Financial Economics, 12, 129-156. http://dx.doi.org/10.1016/0304-405X(83)90031-4

Basu,S. (1977). Investment Performance of Common stocks in relation to Their Price Earning Ratios: A test for the Effecient Market Hypothesis. Journal of Finance, 32, 663-682.

Berk, J.,Green, J., \& Naik, V. (1999). Optimal Investment, Growth Options, and Security Returns. Journal of Finance, 54, 1553-1607. http://dx.doi.org/10.1111/0022-1082.00161

Bhandari,J.S., \& Weiss, L.A. (1996). Corporate Bankruptcy: economic and legal perspectives. Cambridge: Cambridge University. http://dx.doi.org/10.1017/CBO9780511609435

Boni,L., \& Kent, L.W. (2006). Analysts, Industries, and Price Momentum. Journal of Financial and Quantitative Analysis, 41(1), 85-109. http://dx.doi.org/10.1017/S002210900000243X

Carhart, Mark M. (1997). On Persistance in Mutual Fund Performance. Journal of Finance, 52, 57-82.

Chan, K. (1988). On the Contrarian Investment Strategy. The Journal of Business, 61(2), 147-163. http://dx.doi.org/10.1086/296425

Chan, K., Hameed, A., \& Tong, W. (2000). Profitability of Momentum Stragegies in the International Equity Markets. Journal of Financial and Quantitative Analysis, 35 (2), 153-172. http://dx.doi.org/10.2307/2676188

Chan, L., Jegadeesh, N., \& Lakonishok, J. (1996). Momentum Strategies. Journal of Finance, $51,1681-1713$. 
Chan. Louis K.C., Hamao, Y., \& Lakonishok, Josef. (1991). Fundamentals and Stock Returns in Japan. Journal of Finance, 46, 1739-1764.

Chen, J., Benett, A., \& Zheng, T. (2006). Sector Effects in Developed vs. Emerging Markets. Financial Analysts Journal, 62 (6), 40-51. http://dx.doi.org/10.2469/faj.v62.n6.4352

Chen,H.,Chen,S., Hsin,C., \& Lee.C. (2010). Price, Earnings and Revenue Momentum Strategies. http://dx.doi.org/10.2139/ssrn.1571883

Chen,J., Benett, A., \& Zheng,T. (2006). Sector effects in Developed vs. Emerging Markets. Financial Analyst Journal, 62 (6), 40-51. http://dx.doi.org/10.2469/faj.v62.n6.4352

Chopra, N., Lakonishok, J., \& Ritter, J. (1992). Measuring Abnormal Performance: Do Stocks overreact? Journal of Financial Economics, 31, 235-268. http://dx.doi.org/10.1016/0304-405X(92)90005-I

Chordia, T., \& Shivkumar, L. (2002). Momentum, Business Cycle and Time, Varying $\begin{array}{llllll}\text { Expected Returns. Journal of } & \text { Finance, } 57 & \text { (2), 985-1019. }\end{array}$ http://dx.doi.org/10.1111/1540-6261.00449

Chui, A.C.W., Titman, S., \& Kim, J.K.C. (2000). Momentum, Legal Systems and Ownership Structure: An Analysis of Asian Stock Markets. SSRN, working paper series, Social Science, Electronic Publishing.

Claessens, S., Dasgupta, S., \& Glen, J. (1998). The Cross Section of Stock Returns:Evidence from Emerging Markets. Emerging Markets Quarterly, 2, 4-13.

Conrad, J., Kaul, G., \& Nimalendran M. (1991). Components of Short-Horizon Individual Security Returns. Journal of Financial Economics, 29, 365-384. http://dx.doi.org/10.1016/0304-405X(91)90007-7

Conrad, Jennifer, Kaul, \& Gautum. (1993). Long-Term Market Overreaction or Biases in Computed Returns? Journal of Finance, 48 (1), 39-63.

Daniel, K., Hiirshleifer, D., \& Subrahmanyam, A. (1998). Investor Psychology and Security Marekt Under-and-over Reactions. Journal of finance, 53, 1839-1886. http://dx.doi.org/10.1111/0022-1082.00077

Dapaah,A., \& Peiying,L. (2010). Investing in Reits: Contrarian versus Momentum.

De Bondt, W.F., \& Thaler, R. (1985). Do the Stock Markets Overreact? Journal of Finance, 40, 793-805.

De Bondt, W.F., \& Thaler, R. (1987). Further Evidence of Investor Overreaction and Stock Market Seasonality. Journal of Finance, 42, 557-581.

Fama, E.F., \& French, K.R. (1998). Value Versus Growth:The International Evidence. Journal of Finance, 53, 1975-1999. http://dx.doi.org/10.1111/0022-1082.00080

Fama, Eugene F,, French, \& Kenneth R. (1996). Multi-factor Expalnation of Asset Pricing Anomalies. Journal of Finance, 51, 55-84. 
Fama, Eugene F., French, \& Kenneth R. (1993). Common Risk Fators in the Returns on Stocks and Bonds. Journal of Financial Economics, 33, 3-56. http://dx.doi.org/10.1016/0304-405X(93)90023-5

Fama, Eugene F., French, \& Kenneth R. (1992). The Cross-Section of Expected Returns. Journal of Finance, 47, 427-466.

Frankel, J.A., \& Schmukler, S.L. (1996). Country Fund Discounts, Asymetric Information and the Mexican Crisis of 1994: Did Local Residents Turn Pessimistic Before International Investors? Open Economics Review, 7, 511-534. http://dx.doi.org/10.1007/BF01886211

Fraulo, P., \& Nguyen, J. (2009). Do Industries Explain Momentum? - A Replication of Moskowitz and Grinblatt 2004. kanecap.com/doc/williams/.../Fraulo_Nguyen_Econ18_2009.pdf .

Froot, K., O Connell, \& Seasholes, P. (2001). The Portfolio Flows of International Investors. $\begin{array}{llll}\text { Journal of Financial 2515-2547. } & \text { Economics, }\end{array}$ http://dx.doi.org/10.1016/S0304-405X(00)00084-2

Gabbi,G. (2005). Semi-correlations as a tool fot Geographical and Sector Asset Allocation. The European Journal of Finance, 11 (3), 271-281. http://dx.doi.org/10.1080/13518470500039220

Goetzmann, W. N., \& Massa, M. (2002). Daily Momentum and Contrarian Behavior of Index Fund Investors. Journal of Financial and Quantitave Analysis, 37 (3), 375-389. http://dx.doi.org/10.2307/3594985

Grundy, B., \& Martin, S. (2002). Understanding the Nature of Risks and the Sources of Momentum Investing. Review of Financial Studies, 14, 29-78. http://dx.doi.org/10.1093/rfs/14.1.29

Hameed,A., \& Kusnadi,Y. (2002). Momentum Strategies:Evidence from Pacific Basin Stock Markets. Journal of Financial Research, 25 (3), 383-397. http://dx.doi.org/10.1111/1475-6803.00025

Hong, H., Lim, J.C., \& Stien, J. (2000). Bad News Travels Slowly: Size, Analyst Coverage, and the Profitability of Momentum Strategies. Journal of Finance, 55, 265-295. http://dx.doi.org/10.1111/0022-1082.00206

Hong, H., \& Stien,J. (1999). A Unified theory of Underreaction, Momentum Trading and Overreaction in Assets Markets. Journal of Finance, 55, 265-295. http://dx.doi.org/10.1111/0022-1082.00206

Jegadeesh, N., \& Titman, S. (2001). Profitability of Momentum Strategies: An Evaluation of Alternative Explanations. Journal of Finance, 56, 699-720. http://dx.doi.org/10.1111/0022-1082.00342 
Jegadeesh, N., \& Titman, S. (2002). Cross-Sectional and Time Series Determinants of Momentum Returns. Review of Financial Studies, 15, 143-158. http://dx.doi.org/10.1093/rfs/15.1.143

Jegadeesh, N., \& Titman, S. (1995). Overreaction, Delayed reaction, and Contrarian Profits. Review of Financial Studies, 48, 973-993. http://dx.doi.org/10.1093/rfs/8.4.973

Jegadeesh, N., \& Titman, S. (1993). Returns to Buying Winners and Selling Losers: Implications of Stock Market Effeciency. Journal of Finance, 48, 65-91.

Jung, J., \& Shiller, R. (2005). Samuelson's Dictum And The Stock Market. Economic Inquiry, 43 (2), 221-228. http://dx.doi.org/10.1093/ei/cbi015

Kaminsky, G., Lyons. R.K., \& Schmukler, S.L. (2004). Managers, Investors, Crises: Mutual Fund Strategies in Emerging Markets. Journal of International Economics, 64, 113-134. http://dx.doi.org/10.1016/S0022-1996(03)00075-8

Kaul, Guatum, \& Nimalendran, M. (1990). Price Reversals: Bid-ask Errors on Market Overreaction? Journal of Financial Economics, 28, 67-83. http://dx.doi.org/10.1016/0304-405X(90)90048-5

Kent, D., Hirshleifer, D., \& Subrahmanyam, A. (2004). A Theory of Overconfidence, Self-Attribution, and Security Market Under-and-overReactions. Finance 0412006, EconWPA .

Kim, W., \& Wei, S.J. (2002). Foreign portfolio investors before and during a crisis. Journal of International Economics, 56 (1), 77-96. http://dx.doi.org/10.1016/S0022-1996(01)00109-X

Lakonishok, Josef, Shliefer, Andrei, Vishny, \& Robert W. (1994). Contraian Investment, Extrapolation and Risk. Journal of Finance, 49, 1541-1578.

Lee, C., Swaminathan. (2000). Price Momentum and Trading Volume. Journal of Finance, 55, 2017-2069. http://dx.doi.org/10.1111/0022-1082.00280

Lewellen, J. (2002). Momentum and Autocorrelation in Stock Returns. The Review of Financial Studies, 15, 533-573. http://dx.doi.org/10.1093/rfs/15.2.533

Lin, A.Y., \& Swanson, P. (2004). International Equity Flows and Developing Markets: the Asian Financial Market Crisis Revisited. Journal of International Financial Markets, Institutions \& Money, 14, 55-73. http://dx.doi.org/10.1016/S1042-4431(03)00044-1

Lintner, John. (1965). The Valuation of Risky Assets and the Selection of Risky Investment in Stock Portfolios and Capital Budgets. Review of Economics and Statistics, 47, 13-37. http://dx.doi.org/10.2307/1924119

Litzenberg, R. H., \& Ramaswamy,K. (1979). The effect of Personal Taxes and Dividend on Capital Asset Prices: Theory and Empirical Evidence. Journal of Financial Economics, 7 (2).

Liu,L.X., \& Zhang, L. (2008). Momentum Profits, Factor Pricing and Macroeconomic Risk. Review of Financial Studies, 41-66. 
Lo, A., \& MacKinlay, C. (1990). When are Contrarian Profits due to Stock market Overreaction?.. Review of Financial Studies (3), 175-206. http://dx.doi.org/10.1093/rfs/3.2.175

Menzly,L., \& Ozbas,O. (2006). Cross Industry Momentum.

Miffre,J., \& Rallis,G. (2007). Momentum Strategy in Commodity Futures Market. Journal of Banking and Finance, 31 (6), 1863-1886. http://dx.doi.org/10.1016/j.jbankfin.2006.12.005

Moskowitz, T.J., \& Grinblatt, M. (1999). Do Industries Explain Momentum? Journal of Finance, 44, 1249-1290. http://dx.doi.org/10.1111/0022-1082.00146

Naranjo,A., \& Porter,B. (2007). Including Emerging Markets in International Momentum Investment Strategies. Emerging Markets Review, 147-166. http://dx.doi.org/10.1016/j.ememar.2007.01.001

Neal, Edward S. O'. (2000). Industry Momentum and Sector Mutual Funds. Financial Analysts Journal, 37-49. http://dx.doi.org/10.2469/faj.v56.n4.2372

Nijman, T., Swinkels, L., \& Verbeek, M. (2004). Do Countries or Industries explain momentum in Europe? Journal of Empirical Finance, 461-481. http://dx.doi.org/10.1016/j.jempfin.2004.02.001

Patel. S.A. (1998). Cross-Sectional Variation in Emerging Marjets Equity Returns, January 1988-March 1997. Emerging Markets Quarterly, 2, 57-70.

Phylaktis K, \& Xia, L. (2006). Sources of Firms' Industry and Country Effects in Emerging Markets. Journal of International Money and Finance, Elsevier, 25 (3), 459-475. http://dx.doi.org/10.1016/j.jimonfin.2006.02.001

Richards, A.J. (2002). Big Fish in Small Ponds:The Momentum Investing and Price Impact of Foreign Investors in asian Equity Markets. IMF and The Reserve Bank of Australia .

Rosenberg,B., Reid,K., \& Lanstein,R. (1985). Persuasive Evidence of Market ineffeciency. Journal of Portfolio Management, 9-16. http://dx.doi.org/10.3905/jpm.1985.409007

Rouwenhorst, K. (1998). International Momentum Strategies. Journal of Finance, 53, 267-284. http://dx.doi.org/10.1111/0022-1082.95722

Rouwenhorst, K.G. (1999). Local Return Factors and Turnover in Emerging Markets. Journal of Finance, 54, 1439-1464. http://dx.doi.org/10.1111/0022-1082.00151

Safieddine,A., \& Sonti,R. (2007). Momentum and Industry Growth. Review of Financial Economics, 16 (2), 203-215. http://dx.doi.org/10.1016/j.rfe.2006.01.003

Schiereck, D., DeBondt, W., \& Weber, M. (1999). Contrarian and Momentum Strategies in Germany. Financial Analyst Journal, 104-116. http://dx.doi.org/10.2469/faj.v55.n6.2317

Scott, J., Stump, M., \& Xu, P. (2003). News, Not Trading Volume, Builds Momentum. Financial Analysts Journal, 59 (2), 45-54. http://dx.doi.org/10.2469/faj.v59.n2.2513 


\section{Macrothink}

Asian Journal of Finance \& Accounting

ISSN 1946-052X

2012, Vol. 4, No. 1

Scowcroft, A., \& Sefton, J. (2005). Understanding momentum. Financial Analyst Journal, 61 (2), 64-82. http://dx.doi.org/10.2469/faj.v61.n2.2717

Sehgal,S., \& Jain, S. (2011). Long-term prior return patterns in stock and sectoral returns in India.

Sehgal,S., Jain, S. (2011). Short-term Moemntum patterns in stock and sectoral returns:Evidence from India. Journal of Advances in Mangement and Research, 8 (1), 99-122. http://dx.doi.org/10.1108/09727981111129327

Serra, Ana Paula Sousa Freitas Madureira. (2000). Country and Industry Factors in Returns Evidence from Emerging Markets' Stocks. Emerging Markets Review, 1.

Sharpe, W. (1964). Capital Asset Prices: A Theory of market Equilibrium under conditions of Risk. Journal of Finance, 19, 425-442.

Shen, Q.,Szakmary, A.C., \& Sharma, S.C. (2005). Momentum and Contrarian Strategies in International Stock Market: Further Evidence. Journal of Multinational Financial Management, 15, 235-255. http://dx.doi.org/10.1016/j.mulfin.2004.09.001

Swanson,P., \& Lin,A.Y. (2005). Trading Behavior and Investment Performace of U.S. Investors in Global Equity Markets. Journal of Multinational Financial Management, 99-115. http://dx.doi.org/10.1016/j.mulfin.2004.03.006

Torsten, B., Lukas, M., \& Ulrich, S. (2003). The Use of Momentum, Contrarian and Buy-and Hold Strategies. Survey Evidence from Fund Managers. University at Hannover dp-290 .

Vander Hart, J., Slagter, E., \& VanDijk, D. (2003). Stock Selection Strategies in Emerging $\begin{array}{llllr}\text { Markets. Journal of Empirical } & \text { Finance, } & 10, & 105-132 .\end{array}$ http://dx.doi.org/10.1016/S0927-5398(02)00022-1 